\title{
Tax Compliance Decision Analysis: Audit Strategy, Audit Rate, Perceived Probability of Audit, and Taxpayer Ethics
}

\author{
Meinarni Asnawi \\ Cenderawasih University Jayapura Papua, Indonesia \\ meinarni.asnawi@gmail.com
}

\begin{abstract}
This study aims to provide empirical evidence that audit strategy, audit rate, perceived probability of audit and taxpayer ethics have impact on tax compliance. This Research employs the experimental laboratory method with multiple treatment design to refer behavioral change in tax compliance decision. 156 voluntary student participants were recruited from three major; accounting, management, and economics major. The participants grouped into random and fixed group adaptable with audit strategy treatment. Random selection is used to establish participant to each group. Audit rate treatment was classified in four audit level; uninformed audit rate, $10 \%, 20 \%$, and finally $30 \%$. Perceived probability of audit treatment; subjects determine the percentage of perceived audit. Furthermore taxpayer ethics treatment uses tax ethics film. The results provide empirical evidence that in the random group, strategy random audit, audit rate, perceived probability of audit and taxpayer ethics have significant relationship with tax compliance decision. Conversely, fixed group disprove that audit fixed strategy insignificantly with tax compliance decisions. Audit fixed strategy and audit rate have indirect relationship to tax compliance decision by perceived probability of audit. These results from both of group may suggest that taxpayers will increase the tax compliance decision when his possibility to be audited is high. Taxpayer ethics has significant impact on tax compliance decision at all audit level. Taxpayer ethics plays an important role of increased tax compliance decision. This study has implication for judgment theory to consider taxpayer ethics.
\end{abstract}

Keywords: Audit strategy, audit rate, perceived probability of audit, taxpayer ethics and tax compliance decision

\section{Introduction}

Recent studies of tax compliance expand to consider social and psychology factors instead of economics factors. These factors are based on the tax compliance decision which related to morale contract between taxpayers and government (Directorate General of Taxes of Republic Indonesia Direktorat Jenderal Pajak) that taxpayers have to pay for using public facilities. Indonesia applies self-assessment system where a taxpayer is required to assess his tax liability by determining his taxable income, computing his tax liability and submitting his tax returns based on existing tax laws issued by tax authorities. Actually, Indonesia still has great tax potential because the existing number of taxpayers just reached 11,17 million from Indonesia's total population of 242 million (December, 2014). Last couple years tax revenue does not meet the target, e.g. first-half of year 2013, the tax revenue just at 89,1 percent and the end of December 2014, tax acceptance 981,9 trillion. Tax revenue fails to meet the target-tax revenue only reached at 91,5 percent from the set target or 90 trillon tax shortfalls ${ }^{1}$. These fact data may suggest that tax reform conducted by government does not yet reached the aims rising of tax ratio and tax compliance ratio. Currently the ratio of tax compliance in Indonesia, only $13.5 \%$ compared to average ratio of tax compliance in Asia of $20 \%$. The substantial disparity between reachable potential and actual tax denotes that tax compliance is serious problem and it needs to be reviewed carefully.

Tax reform should be not only reforming the tax regulations, but also the tax administration and the strategies to emerge compliance by altering public perception over tax. The increase of tax compliance ratio could raise tax revenue and eventually it could help government in financing development and in paying government debt. Taxpayer compliance can be increased through economic and psychological aspect. Becker

\footnotetext{
${ }^{1}$ See http://www.cnnindonesia.com/ekonomi, MenkeuBambang Brodjonegoro, December 15, 2014.
} 
(1968) is the first author who employs economic approach in conducting the empirical study of tax compliance. Recently, instead of economic approach, many empirical studies emphasize psychological aspect in terms tax compliance (Hanno and Violate, 1996; Milliron, 1985; Milliron and Toy, 1988). Henderson \& Kaplan (2005) extends a model that examines the relationship between ethical beliefs, ethical evaluation and tax compliance. His result provides favorable empirical evidence for explaining the relationship between ethical evaluation and tax compliance proxy by multidimensional ethical scale (MES). Prior studies show that the efforts to increase taxpayer compliance should not ignore economic and psychology factor such as tax payer ethics and audit strategy. This study aims to provide empirical evidence concerning the presence of behavioral changes as attributed to the differences of audit strategy and audit rate over tax compliance decision. Further, this study demonstrates that perceived probability of audit constitutes moderating variable in tax compliance decision. In this study, I also examine taxpayer ethics as a moderating variable between perceived probability of audit and tax compliance decision.

Five important differences with previous studies to this study should be noted. First, this study uses Multidimensional Ethical Scale (MES) to measure taxpayer ethics. Prior studies such as Gosh and Crain (1996) use ethical standard to measure tax ethics. MES has the advantage that it can measure the tax ethics more specifically than general ethics. Second, this study uses experimental method with software and tax video which has customized, so that it simplifies the selection of audited subjects and quickly notices the changes of subjects' attitudes when the treatments given to them. Third, I emphasize two approaches of tax compliance decision. Those are economic (e.g. audit strategy and audit rate) and psychological approach (e.g. perceived probability of audit and taxpayer ethics). Fourth, this study has specific design with respect to the framing of tax case in Indonesia. The framing of the tax case is shifted into gain and loss tax. Previous studies (Poputra, 2009; Makhfatih, 2005; Ghosh \& Crain, 1996) never discovered such this design. Fifth, this study controls several variables that influenced on tax compliance decision, such as tax rate, penalty, and income. Other experimental studies do not employ the control variable, but emphasize on the assumptions (Poputra, 2009; Makhfatih, 2005). This study contributes to literature, methodology, and policy. First, when making ethical decision concerning tax compliance decision should not ignore the factor such as ethics. Second, this experimental design uses structured procedure and has favorable internal validity that accordance with the taxation condition in Indonesia. This favorable experimental method adequate to demonstrate that psychological approach would be better able to predict of the tax compliance decision than expected utility model. Third, this study contributes to better changes of tax audit system by upholding on random audit strategy and to higher audit rate which provides an opportunity for potential audit in enhancing tax compliance.

\section{Literature Review}

Theories underlined Tax Compliance Decision Research: Becker (1968) examines tax evasion that underlined on the criminal economic theory. His result suggests that the probability of detection and the size of fine imposed, determine the amount of income evaded. The Becker model is also applied to tax evasion by Allingham and Sandmo (1972) who use not only the criminal economic theory, but also the agency theory that there is contract between citizen and state in terms of tax payment. Essentially, citizen never formally signed the contract of tax payment; however they must pay payroll tax for income they earned. ${ }^{2}$ There is a psychological tax contract that portrays the relationship between taxpayers and tax authorities. The psychological tax contract is influenced by government policy, tax authorities' behavior, and state institutions (Feld and Frey, 2005), which in turn emerges moral hazard and adverse selection due to asymmetric information between taxpayers and tax authorities and divergence interests among counterparts. Taxpayers, therefore, taken to be a "quasi-voluntary" with emphasis on his self-interest (Levi, 1988). On the other hand, tax authority optimally chooses the way dealing with the taxpayers by acknowledging that external interventions in the form of rewards or sanctions may increase taxpayers' motivation to pay taxes. There are two arguments proposed that there is a gap between theoretical studies and empirical evidence in terms of tax compliance (see the surveys by Andreoni et al., 1998; Slemrod and Yitzhaki, 2002; Torgler, 2003). First, it argues that the probability of being detected is subjective, implying that individual perceptions of being

${ }^{2}$ Tax is a contribution from citizen who owed by individuals or entities that are forced by law, with not a direct reciprocal and used for state purposes to attain the prosperity of the people". See UU No. 28 Tahun 2007 about KetentuanUmumdan Tata Cara Perpajakan. 
caught when cheating on the tax code much higher than objective probabilities of detection. This argument portrays the psychological impact related to tax compliance decision. The second argument is traditional tax compliance that only focuses on the main economic arguments in terms of tax compliance decision. The empirical evidence, however, indicates that the standard economic model is unable to portray the extent of tax compliance in more favorable way (Frey and Feld, 2002).

The certainty on audit encourages taxpayer to make carefully decision. Slemrod et al. (2001) find that taxpayers who informed to be audited may report carefully the income on subsequent period than taxpayers who uninformed to be audited. This finding is consistent with Friedland et al. (1978), Becker et al. (1987), and Webley et al. (2006). In addition to the certainty on audit, the uncertainty of audit also encourages taxpayer to make carefully his tax decision. When government implements the system of audit random, taxpayers tend to report carefully his income, mainly risk-averse taxpayers Snow and Warren (2005) argue that audit selection return, which based on the random strategy and procedure may have impact on the increasing tax compliance. Recently, IRS has re-established audit random programs for estimating tax compliance and has updated audit formula for running audit strategy ${ }^{3}$. IRS has demonstrated the importance of randomization and confidentiality of audit strategy as instruments for enhancing the tax compliance ${ }^{4}$. The studies that describe the impact of audit uncertainty on the increasing of tax compliance decision have been conducted by Spicer and Thomas (1982), Alm et al. (1992a), and Clark et al. (2004). They employs experimental design and provide empirical evidence that the audit random is able to achieve the highest tax compliance. Nevertheless, there are some studies that provide dissimilar result that there is no significant impact of audit on tax compliance (Reiganum and Wilde, 1985; Cowell, 2006; Erad and Feinstein, 1994). The results suggest that tax compliance is not only based on the audit, but also on the perceived probability of audit. The tax compliance increases when taxpayer perceives having opportunity to be audited.

Utility theory affords to explain the appealing findings related to the contradictive of audit probability in terms of elaborating the tax compliance decision. Some studies of tax compliance decision which employing utility theory provide inconsistent evidence (Allais, 1953; Ellsberg, 1961). Futhermore, subsequent studies of tax compliance begin to employ utility theory with various models, such as the rack-dependent expected utility model by Quiggin (1982) and Yaari (1987), the decision weighting model by Kahn and Sarin (1988), and cumulative prospect theory advanced by Tversky and Kahneman (1992). They argue that nobody likes paying taxes, and if in case he has to pay tax, he will maximize his utility firstly. Individual decision to maximize his utility does not only depend on extent to which he obtain the information of audit certainty, but also on extent to which tax savings performed. Taxpayers who risk averse will evade losses due to penalties in case being audited, but risk taker will calculate the extent to which tax savings being performed in case being unaudited. Numerous studies of tax compliance behavioral employ prospect theory. The prospect theory developed by Kahneman and Tversky(1979) whom argue that individual provides different attitudes in decision making in the framing of losses and gains condition. I, therefore, design distinctive tax case in framing of gain and loss. The behavior aspects such as the characteristic of personality and situational factor afford to influence tax compliance decision. The exploration of tax compliance behavior has been developed after the psychological and sociological theories provide important contributions to the studies of tax compliance decision. Some of them are ethical theories such Justice Theory, Relativism Theory, TeleologyEgoism Theory, Deontology Theory, and Teleology-Utilitarianism Theory. Rest (1979), Brandt (1959), Reidenbach (1988), Beck (1991), and Alm (1988) apply ethical theory on the studies of business and accounting behavioral.

Tax Compliance Decision: Compliance is act up to applicable rules. If taxpayer fails to meet his tax obligation, either intentionally or unintentionally, then it may be a decision to conduct noncompliance. Hence, personality characteristic plays an important role in ethical decision-making, whether his decision relies on rational or intuitional decisions (Schwartz, 1967; Grasmick \& Green, 1980; Grasmick \& Scott1982; Kaplan, 1985). Alm and deJuan (1995) examine that economic and non-economic factors influence tax compliance. Their result supported by prospect theory of Kahneman and Tversky (1979) whom convey that individual provides different responses dealing with losses or gains conditions. Alm and Vazquez (2001) employ two

${ }^{3}$ See IRS News Release IR-2002-05, January 16, 2002.

${ }^{4}$ SeeRoberts v. Internal Revenue Service, 584 Federal Supplement 1241 (Eastern District, Michigan), 1984. 
approaches to examine taxpayer compliance. First, they treat taxpayer as a potential criminal subject, which the approach has impact on audit frequency and penalty for noncompliance tax efforts. Second, they examine the social institution's role in term of portraying taxpaying compliance. The second approach has impact on social norm and the tax authority administration. Uppal (2005) conducts tax compliance study in Indonesia. He measures tax compliance rate by employing ratio between number of taxpayers whom fill in tax report and of registered potential taxpayers. The result shows that tax compliance rate in Indonesia equivalent to 2.5 percent of total registered taxpayers. This result suggests that tax compliance rate in Indonesia is low. Recently, tax compliance rate in Indonesia goes up to 13.3 percent, less than average rate of tax compliance in Asia. The low rate of tax compliance leads Indonesia lost the potential tax revenues, unfavorable taxation system, and unreliable tax for sources of revenues. The disadvantage implications contradict the government's effort to promote revenues from taxes.

Audit Strategy: Preliminary studies portray tax compliance modeling as a game between taxpayer and tax authority because there are conflicting interests concerning taxpayers' welfare maximization and government's revenues maximization (Beck, 1989; Reiganum and Wilde, 1985). Alm et al. (1993) argue that there are several ways and strategies for tax audit selection, namely random audit rule and fixed audit rule. Numerous studies provide empirical evidence that random audit strategy will enhance tax compliance because non-compliant taxpayers tend to avoid the penalty risk (Ghosh and Crain, 1996; Beck, 1991; Jackson and Milliron, 1986). Prior studies clarify that the assumption of asymmetric information between Dirjen Pajak (principal) and taxpayer (agent) perhaps require monitoring. The objective of monitoring is to accurately capture whether taxpayer performs compliance or vice versa. In context of tax, monitoring closes to examination which performed by Dirjen Pajak. This examination aims to avoid the possibility of moral hazard or adverse selection which performed by taxpayers when they fill in the tax report (SPT). Thus, when determining the date and the reason of taxpayer's examination should consider appropriate examination strategy. The hypotheses, therefore, proposed as follows:

H1a. Random audit strategy has positive impact on tax compliance decision.

H1b. Fixed audit strategy has positive impact on tax compliance decision.

H1c. Random audit strategy has more impact on the increasing tax compliance decision than fixed audit strategy.

Audit Rate/Level: Higher audit rate, higher tax compliance. Consequently, higher possibilities of taxpayer to be examined which in turn has impact on taxpayer attitude that may be more conservative. Friedland et al. (1978) find that decreased audit rate in random audit strategy will have impact on probability of increased income taxable report. This finding is consistent with Beck (1991), Alm (1991), and Alm et al. (1992a, 1993) that find tax compliance increased when audit rate is higher in random audit strategy. The decreased of audit rate has impact on the decreased of collecting tax income (Dubin et al., 1990). Dubin (2004) finding support previous empirical evidence that the decreased of audit rate has impact on the decreased of tax compliance decision. In contrary, Slemrod et al. (2001) do not provide actual information about individual tax compliance because their experiment employs reported tax data, not the actual tax data. Thus, this study investigates the following hypotheses:

H2a. Audit rate has impact on the increased tax compliance decision.

$\mathrm{H} 2 \mathrm{~b}$. The Increased audit rate has positive impact on the increased tax compliance decision.

Perceived Probability of Audit: Numerous empirical evidence explore the impact of perceived probability of audit on tax compliance. Milliron and Toy (1988) investigate seven key compliance features and they imply that audit probability determines tax compliance decision. Alm (1988) investigates perceived probability of audit that relies on a relationship between the principal (tax institution) and the agent (taxpayer). The relationship between tax authority and taxpayer generates audit selection rules. If individual report income lower than the cutoff level, he is more likely will be audited, and vice versa. Kahneman \& Tversky (1979) provide empirical evidence that individual considers that the probability of being audited is lower, so individual systematically believes that their audit probability is lower than actual probability. According to explanations above, it implies that individual will report income which possible to him not to be audited by considering the possibility of being audited. This finding is consistent with Ghosh and Crain (1996) whom provide empirical evidence that higher perceived probability of audit, lower tax noncompliance rate Beck and Jung (1991) also find that reported income increased when perceived probability and penalty rate increased. 
Taxpayer who under uncertainty condition of audit probability tends to be conservative and avoid noncompliance (Jackson and Milliron, 1986; Beck et al.1989). According to explanations above, this study examines the following hypotheses:

H3a. Perceived probability of audit has positive impact on tax compliance decision.

H3b. Random audit strategy has positive impact in increasing tax compliance decision through perceived probability of audit.

H3c. Fixed audit strategy has positive impact in increasing tax compliancedecision through perceived probability of audit.

H3d.The increased audit rate has positive impact in increasing tax compliance decision through perceived probability of audit.

Taxpayer Ethics: Prior studies examine the role of ethics on tax compliance such as Schwartz and Orleans (1976) that focus on social commitment aspect to tax compliance. Later, Jackson and Miliron (1986) develop the study by defining ethics in two measurements of ethical orientations and ethical evaluations. Grasmick and Green (1980), Grasmick and Scott (1982), Kaplan and Reckers (1985), and Reckers et al. (1994) define tax noncompliance behavior as judgment that behavior is morally fault or immoral. Their results suggest that there is a positive relationship between ethics and tax compliance, but Webley and Eidjar (2001) provide negative evidence. Ghosh and Crain (1996) define ethics as feeling that individual will manipulate in order to achieve his goal called intentional noncompliance tax. Henderson \& Kaplan (2005) finding shows that ethics orientation affects ethics evaluation and in which turn positively affects tax compliance. He develops a model that portrays directly and indirectly relationship among ethics orientation, ethics evaluation, and tax compliance. Psychological process of tax ethics depends on self-determination and self-esteem influenced by tax audit, because tax institution able to use tax audit for enhancing tax morale in terms of taxpayer having higher self-determination (Deci et al., 1999). It concludes that individual behavioral play a role of decision making concerning tax compliance. Systematically, tax institution affects morale and tax ethics, so that taxpayers voluntarily willing to pay tax. There is a psychological contract between taxpayer and tax institution in terms of determining fiscal changes including loyalty and ethics of counterparts (Feld and Frey, 2005). Theological theory provides basic understanding for individual in decision-making and realizes the consequences of his decision. This understanding conforms to individual decision concerning tax compliance decision, because he must accept the consequences of either compliant or noncompliant. This research employ MES to test taxpayer ethics. Shaub (1994) reveals that using MES is more favorable measurement than others (e.g. defining issues test or general ethics) because it particularly identifies the rationalization behind morale reasoning and provides an understanding of respondents' reasons believing particular behavior as ethical behavior. According to prior studies, this study examines following hypotheses:

H4a. Taxpayer ethics has impact on increased tax compliance decision.

H4b. Taxpayer ethics moderates a relationship between perceived probability of audit and tax compliance decision attributed to existing of random audit strategy.

H4c. Taxpayer ethics moderates a relationship between perceived probability of audit and tax compliance decision attributed to existing of fixed audit strategy.

\section{Methodology}

Experimental Design: This study uses experimental method because it can capture taxpayer behavior and economic factor regarding the influences toward tax compliance. In order to prevent maturation, I create attractive experiment by using audiovisual (video) and software application. The video contains film that reflects multidimensional ethics such as relativism, contractual and moral equity. It also contains particular treatment for taxpayer ethics with multiethicalscale (MES)design that adopts taxation condition in Indonesia. The software application contains experimental treatment for subjects. The treatments consist of numerous conditional questions that reflect audit strategy, perceived probability of audit, and taxpayer ethics with measurement items and manipulation check regarding tax compliance. This research uses laboratory experiment with multiple treatment design. According to Kardes (1996), experimental method provides maximum results as if the subjects close to the real phenomena. Thus, the subjects of this study are graduate and post-graduate students with various major. The subjects, on average, have been imposed tax liability for 
income they earned and have performed tax paying activities. Total number of subjects is 156 students. All of participants studies at Faculty of Economic and Business of Universitas Gadjah Mada with accounting, management, and economics major. The subjects are grouped into two group based on audit strategy, namely random and fixed audit strategy. Audit level consists of uninformed and informed about the level. For uninformed level, the subjects do not know the level of audit. Conversely, the informed subjects know the audit level which consists of level of 10 percent, 20 percent, and 30 percent. The following table describes experimental design. Futhermore, The subjects watch the video before answer the ethics questionnaire on software application.

Descriptive Statistics: The experimental subjects recruited from three major, namely 96 subjects of accounting major (61 percent), 51 subjects of management major (33\%), and 10 subjects of economics major (6 percent). Subjects of 96 have worked and of 60 have not worked before. These demographic results conform to author's expectation that subjects constitute taxpayers and potential taxpayers. The subjects grouped into random group and fixed group. The manipulation test results show significance level of 0.000 for all treatments including audit strategy, audit rate, perceived probability of audit, and taxpayers' ethics. These results indicate that all of subjects have known and understood well of each procedure, and have similar interpretation concerning the given treatments. In other words, manipulation test results of experimental treatment are effective. The test results of instrument quality indicate that all of measurement items meet the standard. The results of each test show that the score of each indicator are greater than score of 0.6. The whole employed constructs meet the reliability and validity requirement because composite reliability and conbrach alpha are above the score of 0.7 .

\begin{tabular}{|c|c|c|}
\hline Group & Random & Fixed \\
\hline Total Subjects & 78 & 78 \\
\hline \multicolumn{3}{|l|}{ Treatments: } \\
\hline \multirow[t]{2}{*}{$\begin{array}{l}\text { Audit Strategy } \\
\text { Audit Level/Rate }\end{array}$} & $\begin{array}{l}\text { Random } \\
\text { uninformed audit level }\end{array}$ & Fixed \\
\hline & $30 \%$ & $20 \%$ \\
\hline Perceived probability of audit & $\begin{array}{l}\text { Subjects determine the } \\
\text { percentage of perceived audit. }\end{array}$ & $\begin{array}{l}\text { Subjects determine the } \\
\text { percentage of perceived } \\
\text { audit }\end{array}$ \\
\hline Taxpayer Ethics & $\begin{array}{l}\text { Subjects are shown video } \\
\text { regarding regulations and tax } \\
\text { fraud }\end{array}$ & $\begin{array}{l}\text { Subjects are shown video } \\
\text { regarding regulations and } \\
\text { tax fraud }\end{array}$ \\
\hline
\end{tabular}

\section{Results}

This study applies SmartPLS to evaluate structural model by pointing out R-square for dependent variable and coefficient scores of path $(\beta)$ for independent variable. Validity test of random and fixed group show that the proposed model is fit because GoF score closes to 1 (random group score equivalent to 0.693526768 and fixed group score equivalent 0.691364291 ). The random group treated with uncertainty audit level that means each subject has same audit possibility. The percentage of taxpayers ethics equivalent to 31 percent is highest than other variables, therefore, taxpayers ethics is key feature in capturing tax compliance decision. Audit rate and perceived probability of audit have significant relationship with tax compliance decision. The R-square score of 51.7 percent indicates that the percentage of all independent variables contribute to tax compliance decision is 52 percent. Fixed group is. In other words, the subjects of fixed group will be audited as if taxable income is overpaid. The result show that fixed audit strategy provides direct effect with coefficient of 0.16 , but it is insignificant affect on tax compliance (prob. > 0.05). Taxpayers ethics contributes coefficient of 0.21 on tax compliance. All of relationships are significant at level of 0.05 . Table 1 is the summary results of random and fixed group. 


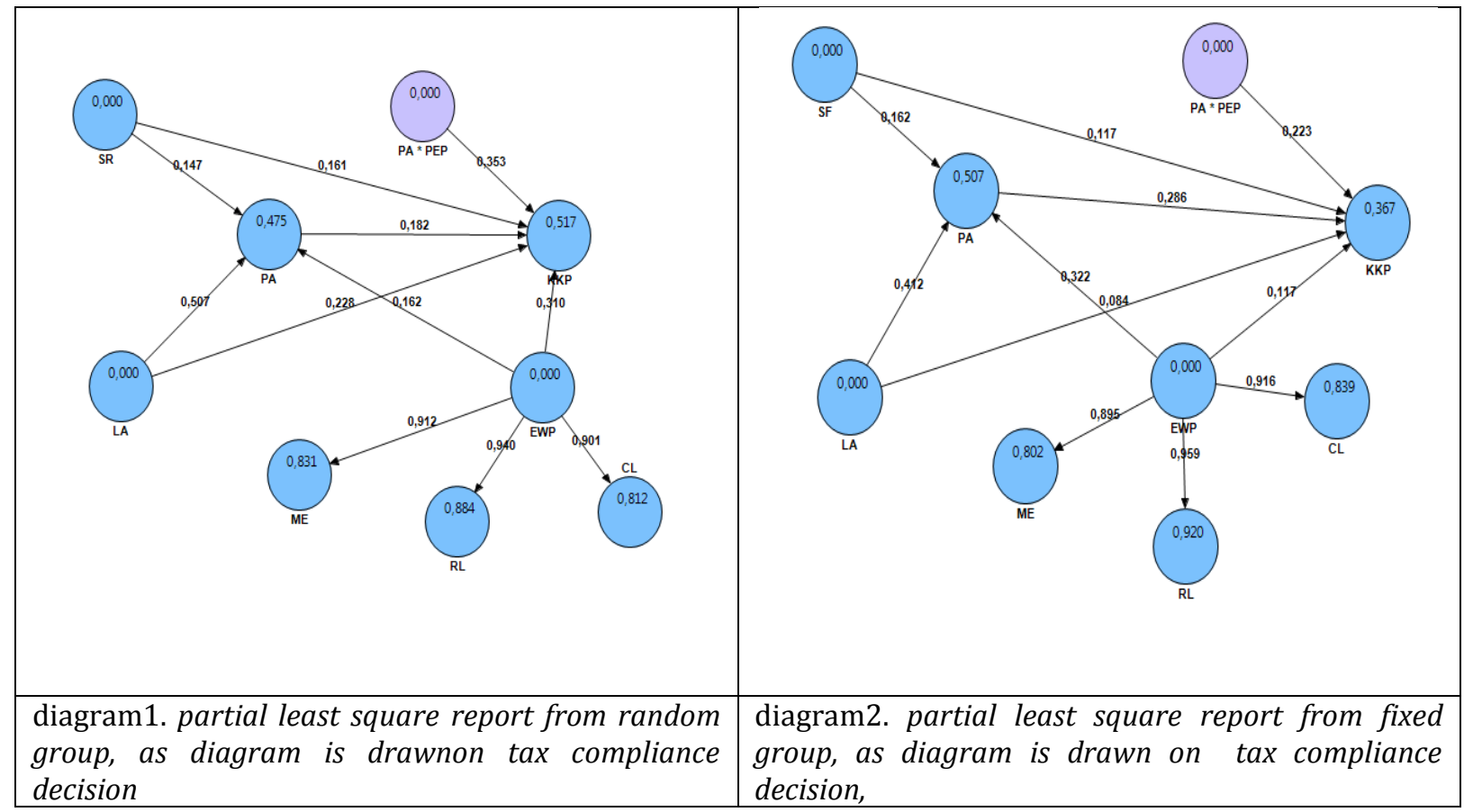

Table 1: The Results Summary of Random and (Fixed) Audit Strategy

\begin{tabular}{llll}
\hline No & Hypotheses & t-value & Results \\
\hline 1 & $\begin{array}{l}\text { H1a.Random audit strategy has positive impact on tax compliance } \\
\text { decision.(supported) }\end{array}$ & 2,725091 & Significant \\
2 & $\begin{array}{l}\text { H1b.Fixed audit strategy has positive impact on tax compliance } \\
\text { decision. (unsupported) }\end{array}$ & Insignificant \\
3 & $\begin{array}{l}\text { H2a. Audit rate has impact on the increased tax compliance } \\
\text { decision. (supported) }\end{array}$ & $\begin{array}{l}3,985569 \\
(2,340224)\end{array}$ & Significant \\
4 & $\begin{array}{l}\text { H3a. Perceived probability of audit has positive impact on tax } \\
\text { compliance decision.(supported) }\end{array}$ & Significant \\
5 & $\begin{array}{l}\text { H3b. Random audit strategy has positive impact in increasing tax } \\
\text { compliance decision through perceived probability of audit. }\end{array}$ & Significant \\
(supported) & $\begin{array}{l}\text { H3c. Fixed audit strategy has positive impact in increasing tax } \\
\text { compliance decision through perceived probability of audit. } \\
\text { (supported) }\end{array}$ & Significant \\
5 & $\begin{array}{l}\text { H4a. Taxpayer ethics has impact on increased tax compliance } \\
\text { decision.(supported) }\end{array}$ & Significant \\
7 & $\begin{array}{l}\text { H4b. Taxpayer ethics moderates a relationship between perceived } \\
\text { probability of audit and tax compliance decision attributed to } \\
\text { existing of random audit strategy.(supported) }\end{array}$ & Significant \\
8 & $\begin{array}{l}\text { H4c. Taxpayer ethics moderates a relationship between perceived } \\
\text { probability of audit and tax compliance decision attributed to } \\
\text { existing of fixed audit strategy. (supported) }\end{array}$ & Significant \\
\hline
\end{tabular}

Sig. t-value $>1,94$

Table 1 provides empirical evidence that random audit strategy increases tax compliance decision than fixed audit strategy, therefore, hypothesis H1b supported. Multiple treatment design test within subjects shows that audit rate of 10 percent, 20 percent, and 30 percent denote the increased tax compliance. Audit level of random group have impact on tax compliance with audit rate of 10 percent and 30 percent (sign. $t>1.94$ ), whereas audit level of fixed group has impact on tax compliance at all level audit of 10 percent, 20 percent, 
and 30 percent. These results indicate that audit level having impact on the increased tax compliance decision is higher, therefore, hypothesis $\mathrm{H} 2 \mathrm{~b}$ supported. Indirect relationship shows significant result on all of audit level. These results may suggest that taxpayers will increase the tax compliance decision when his possibility to be audited is high. Fully mediation generated for indirect relationship between audit level and tax compliance decision through perceived probability of audit (AL $\rightarrow$ PCP $\rightarrow$ TCD) at audit level of 10 percent, 20 percent and, 30 percent. Taxpayer ethics (TPE) has significant impact on tax compliance decision at all audit level with t-value of above 1.94 .

Discussion: Previous studies provide empirical evidence that random audit strategy has more significant impact than fixed audit strategy's impact on increased tax compliance decision. It indicates that taxpayer with higher uncertainty audit will be more compliant than taxpayer with certainty audit. Alm et al. (1993), Ghosh and Crain (1996), Beck (1991), and Jackson and Milliron (1986) provide similar results. This study's result may suggest that taxpayer of fixed audit strategy gains learning process when he determines the amount of taxable income reported. It means taxpayer will perform trial and error for initial reporting. This learning process induces taxpayers to assure the period of being audited and unaudited. In contrast with random audit strategy, all taxpayers has same opportunities to be audited for tax reporting, so that taxpayers will determine the amount of taxable income more carefully. Audit level of fixed audit group shows significant influence on the increasing of tax compliance decision at either uninformed or informed audit level $(10,20$, and 30 percent) This finding may indicate that there is certainty for taxpayer likely audited Taxpayers, therefore, will determine the amount of taxable income carefully. In contrast with fixed audit group, there is appealing finding of the influence of audit level in random audit group. The finding shows that there are significant influence at uninformed audit level and at audit level of 10 percent and 30 percent. There is significant influence of increased tax compliance when audit level of 10 percent and in contrary, become insignificant when audit level turns into level of 20 percent, and is significant when audit level increases to level of 30 percent. These results may attribute to subjects begin to fully appreciate when audit level of 30 percent, so that when audit level of 20 percent the influence is insignificant toward tax compliance decision These findings are consistent with Friedland and Rutenberg (1978), Beck (1991), Alm (1991), and Alm et al. (1992a,1993).

Perceived probability of audit of audited taxpayers is substantial variable for tax compliance decision because it will induce taxpayer to determine the amount of taxable income carefully. This finding provides empirical evident that perceived probability of audit influences the increased of tax compliance decision either as a dependent variable or a moderating variable in both random and fixed group. The findings are consistent with Alm (1988), Gosh and Crain (1996). In fixed group, the perceived probability of audit has dominant impact on increasing tax compliance. It attributes to taxpayers make decision whether they will be audited or not, so that if there is audit uncertainty then they will report the taxes carefully. Initially, in random audit group, taxpayers have high uncertainty of audit, so that the score of perceived probability of audit decreased at low-level audit, vice versa. Taxpayers, therefore, the perceived probability of audit at uninformed audit level is high because uncertainty audit is high and they will report the taxes carefully. Taxpayer ethics contributes to tax compliance either in random or fixed group. These findings are consistent with Henderson \& Kaplan (2005). Ethical values such as moral equity, relativism and contractualism, can raise taxpayer awareness and eventually affect tax compliance decision. Moral equity, relativism and contractualism reflect social and individual norms. Certainly, taxpayers consider these values in determining the taxes reporting. The findings provide empirical evidence that taxpayer ethics has impact on increased tax compliance decision either directly or indirectly. Taxpayer ethics plays an important role of increased tax compliance decision because it based on culture, religion, and tax norms that provide completely comprehension over taxation.

\section{Conclusion}

Taxpayer with random audit strategy tends to be more compliant than with fixed audit strategy. This attributed to taxpayer with random audit strategy has highly uncertainty audit. In respect with uninformed audit level/rate, audit level of 10, 20, and 30 percent, the results are significant toward increased tax compliance for both audit strategies. The results provide empirical evidence that perceived probability of audit affect the increased of tax compliance decision. The perceived probability of audit is not only as dependent variable, but also as moderating variable concerning with the relationship between audit strategy 
and tax compliance. Likewise, concerning with the relationship between audit level and tax compliance, perceived probability of audit serves as moderating variable. This study finds two important variables, namely perceived probability of audit and tax compliance ethics. The interaction effect of both variables shows that the higher perceived probability of audit and tax compliance ethics, the higher tax compliance decision, vice versa. Taxpayer whom aware of his obligation as a citizen and of the tax benefits will be compliant paying tax. This study has implication for government efforts to increase tax compliance. Government should consider audit policies; promote ethical values of taxpayers in education institutions; continuously provide sustainable tax counseling for societies. Moreover, this study has implication for judgment theory to consider individual ethics. This study has five limitations. First, this study only controls three extraneous variables, such as income, tax rate, and penalty. Second, the experimental consists of six sessions that likely provide different bias in historical effect. Third, the limited capacity of experimental laboratory causes the subjects quickly count the number of audited subjects at each audit level treatment, so that uncertainty audit decreased. Fourth, there is maturation effect attributed to simultaneously session shift. It would be to conduct new experiments with appropriate experimental design to have subjects understand on proposed variables. It would also be to improve research design regarding risk preference. Future study should stress on both risk averse and risk taking.

\section{References}

Allais, M. (1953). Le Comportement de l'Homme Rationnel devant le Risque: Critique des Postulats et Axiomes de l'Ecole Americaine. Econometrica, 21(4), 501-46.

Allingham, M. G. \& Sandmo, A. (1972). Income Tax Evasion: A Theoritical Analysis. Journal of Public Economics, 1, 323-338.

Alm, J. \& McKee, M. (2006). Audit Certainty, Audit Productivity and Taxpayer Compliance. National Tax Journal, 59(4), 801-816.

Alm, J. \& McKee, M. (1998). Extending the Lessons of Laboratory Experiments on Tax Compliance to Managerial and Decision Economics. Managerial and decision Economics, 19(4-5), 259-275.

Alm, J. \& Vazquez, M. (2001). Societal Institutions and Tax Evasion in Developing and Transition Countries. Paper presented at the Conference Public Finance in Developing and Transition Countries, Atlanta, Georgia.

Alm, J., Jackson, B. R. \& McKee, M. (1992). Estimating the Determinants of Taxpayer Compliance With Experimental Data. National Tax Journal, 45, 107-114.

Alm, J., Jackson, B. \& McKee, M. (1992a). Deterrence and Beyond: Toward a Kinder, Gentler IRS, in Why People Pay Taxes: Tax Compliance and Enforcement, edited by J. Slemrod. Ann Arbor: University of Michigan Press, 311-29.

Alm, J., Cronshaw, M. B. \& McKee, M. (1993). Tax Compliance With Endogenous Selection Rules. KYKLOS, 46(1), 27-45.

Alm, J., Sanchez. I. \& Juan, A. D. (1995). Economic and Non-economic Factors in Tax Compliance. KYKLOS, 48(1), 8-18.

Alm, J. (1988). Uncertain Tax Policies, Individual behavior and Welfare. The American Economic Review, 27, $237-245$.

Alm., J. (1991). A Perspective on the Experimental Analysis of Taxpayer Reporting. The Accounting Review, 66(3), 577-593.

Andreoni, E. B. \& Freinsteind, J. (1998). Tax Compliance.Journal of Economic Literature, 35 (2), 818-860.

Beck, P. J. \& Jung, W. (1991). Experimental Evidence on Tax Payer Reporting Under Uncertainty. The Accounting Review, 66, 535 - 558.

Becker, G. (1968). Crime and punishment: An economic approach. Journal of Political Economy, 76, 169-217.

Becker, W., Buchner, H. \& Sleeking, S. (1987). The Impact of Public Transfer Expenditures on Tax Evasion. Journal of Public Economics, 34(2), 243-252.

Brandt, R. B. (1959). Ethical Theory: The Problems of Normative and Critical Ethics. Cincinnati, Ohio: Englewood Cliffs, N.J.

Clark, J., Friesen, L. \& Muller, A. (2004). The Good, the Bad, and the Regulator: An Experimental Test of Two Conditional Audit Schemes. Economic Inquiry, 42(1), 69-87.

Cowell, F. (2006). Cheating the Government: The Economics of Tax Evasion. In Do Audit Enhance Compliane? An Empirical Assessment of VAT Enforcement. National Tax Journal, 59(4), 817-832. 
Deci, E. L., Koestner, R. \& Ryan, R. M. (1999). A meta-analytic Review of Experiments Examining The Effects of Extrinsic Rewards on Intrinsic Motivation. Psychological Bulletin, 125, 627-668.

Dubin, A. J., Graetz, M. J. \& Wilde, L. L. (1990). The Effect of Audit Rate on the Federal Individual Incoem Tax 1977-1986. National Tax Jornal, 43(4), 395-409.

Dubin, A. J. (2004). Criminal Investigation Enforcement Activities and Taxpayer Noncompliance. California Institute of Technology. Mimeo Direktur Jenderal Pajak. 2000, Jakarta Post, Vol. July 31.

Ellsberg, D. (1961). Risk, Ambiguity, and the Savage Axioms. Quarterly Journal of Economics, 75(4), 643-69.

Erad, B. (2006). The Influence of Tax Audit on Reporting Behavior. In Do Audits Enhance Compliance? An Empirical Assesment of VAT Enforcement By Bergman.,M and Navarez.,A. National Tax Journal, 59(4), 817-832.

Erad, B. \& Feinstein, J. (1994). The Role of Moral Sentiments and Audit Perceptions in Tax Compliance. Public Finance, 49, 70-89.

Feld, L. P. \& Frey, B. S. (2005). Tax Compliance as The Result of a Psychological Tax Contract: The Role of Incentive and Responsive Regulation. Working Paper.June 76. Center for Tax System Integrity Research School of Social Sciences Australian National University.

Feld, L. P. \& Frey, B. S. (2002). The Tax Authority and Taxpayer: An Exploratory Analysis. Unpublished Manuscript, University of Zurich.

Friedland, N., Maital, S. \& Rutenberg, A. (1978). A Simulation Study of Income Tax Evaluation. Journal of Public Economics, 10(2), 107-116.

Ghosh, D. \& Crain, T. L. (1996). Experimental Investigation of Ethical Standards and Perceived Probability of Audit on Intentional Noncompliance. Behavioral Research in Accounting, 8, 219-244.

Grasmick, H. G. \& Green, D. E. (1980). Legal Punishment, Social Disapproval and Internalization as Inhibitors of Illegal Behavior. Journal of Criminal Law and Criminology, 71(3), 325-335.

Grasmick, H. G. \& Scott, W. J. (1982). Tax Evasion and Mechanism of Social Control : A Comparison with Grand Petty and Theft. Journal of Economic Psychology, 2, 213-230.

Hanno, M. D. \& Violette, G. R. (1996). An Analysis of Moral and Social Influences on Taxpayer Behavior. Behavioral Research in Accounting, 8, 57-75.

Henderson, C. B. \& Kaplan, S. E. (2005). An Examination of the Role of Ethics in Tax Compliance Decisions. JATA, 27(1), 39-72.

Jackson, B. R. \& Milliron, V. C. (1986). Tax Compliance Research: Findings, Problems and Prospect. Journal of Accounting Literature, 5, 125-157.

Kahn, B. E. \& Sarin, R. K. (1988). Modeling Ambiguity in Decisions under Uncertainty. Journal of Consumer Research, 15(2), 265-72.

Kahneman, D. \& Tversky, A. (1979). Prospect Theory: An Analysis of Decision Under Risk. Econometrica, 47, 263-291.

Kaplan, S. E. \& Reckers, P. M. J. (1985). A Study of Tax Evasion Judgments. National Tax Journal, 38, 97-102.

Kardes, F. (1996). In Defense of Experimental Consumer Psycology. Journal of Consumer Psycology, (3), 279 296.

Levi, M. (1988). Of Rule and Revenue. Berkeley: University of California Press.

Makhfatih, A. (2005). Penggelapan Pajak di Indonesia : Studi Pajak Hotel Non Bintang. Unpublished Disertasi, Universitas Gadjah Mada, Yogjakarta.

Milliron, V. C. (1985). A Behavioral Study of The Meaning and Influence of Tax Complexity. Journal of Accounting Research, 23(2).

Milliron, V. C. \& Toy, D. R. (1988). Tax Compliance: An Investigation of Key Features. Journal of the American Taxation Association, 9(2), 84-104.

Poputra., A. T. (2009). Ketaatan Pajak Penghasilan Di Indonesia.Disertasi, Universitas Gadjah Mada, Program M.Si and Doktor Fakultas Ekonomika dan Bisnis UGM, Yogyakarta.

Quiggin, J. (1982). A Theory of Anticipated Utility. Journal of Economic Behavior and Organization, 3(4), 32343.

Reiganum, J. F. \& Wilde, L. L. (1985). Income Tax Compliance in Principal-Agent Framework. Journal of Public Economics, 16, 265-288.

Reckers, P. M. J., Sanders, D. L. \& Roark, S. J. (1994). The Influence of Ethical Attitudes on Taxpayer Compliance. National Tax Journal, 47, 825-836.

Rest, J. (1979). Development in judging moral issues. Minneapolis, MN: University of Minnesota Press

Schwartz, R. D. \& Orleans, S. (1967). On Legal Sanction. University of Chicago Law'Review, 34, 274-300. 
Slemrod, B. M. \& Christian, C. (2001). Taxpayer Response to An Increased Probability of Audit: Evidence From a Controlled Experiment in Minnesota. Journal of Public Economics, 79(3), 455-483.

Slemrod, J. \& Yitzhaki, S. (2002). Tax avoidance, evasion, and administration, Handbook of Public Economics, in: A. J. Auerbach \& M. Feldstein (ed.), Handbook of Public Economics, edition 1, volume 3, chapter 22, pages 1423-1470 Elsevier.

Shaub, M. (1994). An Analysis of The Association of Traditional Demographic Variables with The Moral Reasoning of Auditing Students and Auditors. Journal of Accounting Educations, 2, 1-26.

Snow, A. R. \& Warren, S. Jr. (2005). Ambiguity about audit probability, tax compliance, and taxpayer welfare, Economic Inquiry.

Spicer, M. W. \& Thomas, J. E. (1982). Audit Probabilities and the Tax Evasion Decision: An Experimental Approach. Journal of Economic Psychology, 2(3), 1982, 241-45.

Schwartz, R. D. \& Orleans, S. (1967). On Legal Sanction. University of Chicago Law Review, 34, 274-300.

Torgler, B. (2003). Tax`Morale and Tax Compliance: A Cross Culture Comparison. Copyright of Proceedings of Annual Conference on Taxation.

Trivedi, V. U., Mohamed, S. \& Lynn, B. (2003). Impact of Personal and Situational Factors on Taxpayer Compliance : An Experimental Analysis. Journal of Business Ethics, 47(3), 175-197.

Tversky, A. \& Kahneman, D. (1992). Advances in Prospect Theory: Cumulative Representation of Uncertainty. Journal of Risk and Uncertainty, 5(4), 297-323.

Uppal, J. S. (2005). Kasus Penghindaran Pajak di Indonesia. Economic Review Journal, 201, 1 - 5.

Webley, P., Cole, M. \& Eidjar, O. (2001). The Prediction of Self-reported and Hypothetical Tax Evasion : Evidence From England, France and Norway. Journal of Economic Psychology, 22(2), 141-155.

Webley, P., Robben, H., Elffers, H. \& Hensing, D. (2006). Tax Evasion: An Experimental Approach, In Audit Certainty, Audit Productivity and Taxpayer Compliance. National Tax Journal, 59(4), 801-816.

Yaari, M. (1987). The Dual Theory of Choice under Risk. Econometrica, 55(1), 95-115. 